\title{
A Project-based Approach to Examine University Teachers' Attitudes towards Visually Impaired Students
}

\author{
Eugene Allevato $^{1 *}$ and Moayad Al Marrar ${ }^{2}$ \\ ${ }^{1}$ Department of psychology, USA
}

${ }^{2}$ Department of Pharmacology, USA

*Corresponding author: Eugene Allevato, Department of psychology, USA

Received: 战 April 25, 2019

Published: 㘹 May 01, 2019

\begin{abstract}
A case study was conducted that included an interview of a visually impaired (VIP) psychology student and a survey of teachers' attitudes towards VIP students. A project-based approach was utilized to teach statistics to the VIP student. A survey to examine teachers' attitudes towards the VIP student was prepared as part of a course assignment. This study utilized a mixed-method approach integrating qualitative and quantitative research. Data from 64 faculty members was collected via survey. The results of the study revealed that $33 \%$ of the teachers had positive attitudes toward VIP students. Factor analysis indicated that teachers' attitude has three components explaining $52 \%$ of the total variance: 1 - Teacher's confidence to teach the visually impaired, 2 Lesson impact due to the presence of the visually impaired in a regular classroom, and 3- the recognition of the visually impaired contribution to the enrichment of the classroom experience. These factors seem to indicate that experience with teaching the visually impaired enhance teacher's confidence to teach the visually impaired and recognition of the visually impaired contribution. Obtained results show significant difference with respect to teachers' confidence (p-value 0.005 ) in their ability to effectively teach the VIP. There was also a significant difference in the perception of the VIP contribution to benefit the entire class ( $p$-value 0.024). However, the belief that teachers had to alter the lesson plan because of the presence of the VIP student in class was not significant. Most teachers had varying views and preconceived misconceptions about teaching the visually impaired and claimed the major challenge would be to describe visuals. The study concluded that positive attitude of teachers towards the visually impaired was dependent on whether or not they had previous exposure to visually impaired people. Moreover, this study supports the claim that inclusive education with the necessary resources, and supportive teachers may contribute to the visually impaired students' academic success. The study led to relevant teaching model suggestions for VIP students towards inclusive education.
\end{abstract}

\section{Introduction}

Students with visual impairment have educational needs that are unique and mostly met through a combination of efforts by parents, professional and students. It is a long-held position that subjects involving visual arts, mathematics and science offer instructional challenges in mainstreaming the visually impaired student [1] report that achievements in mathematics by visually impaired students tend to be below their performance in other academic subjects. However, [2] suggests that training for teachers and supportive materials improve mainstreaming and levels of higher education available to the VIP. In order to meet their unique needs, it is important to provide VI students with specialized services and materials such as proper media and books [3] These are tools that are important in enabling them to compete with their peers and take part in various roles of society[3]. It is important that the education sector comes up with a full range of options and programs in which the service providers can create an appropriate environment for each visually impaired student The California Education Code recognizes there is no adequate technology to translate complex mathematical concepts for the profoundly blind. Therefore, a human helper is the best way to create equal access. Instructors need to verbalize everything they write and be precise with their language. Not only can the visually impaired student create a graph and draw geometric constructions, with the right tools; they can often benefit non-disable students [4] It is very important for all students to use as many senses as possible when learning and the inclusion of the visually impaired student in a regular classroom is beneficial to sighted students. A study of around 1,000 primary school students in the United States state of Indiana found positive impacts of inclusion on the progress of nondisabled students in mathematics[5] . 
The National Federation of the Blind (NFB) stated, "The real problem of blindness is not the lack of eyesight. The real problem is the misunderstanding and lack of information which exist. If a blind person has proper training and opportunity, blindness is only a physical nuisance" (1999). Furthermore, recently at the NFB website it is posted: "Every day we raise the expectation of the blind people, because low expectations create obstacles between the blind and our dreams" (2017). In fact, the inclusion of the VIP in a regular classroom would enrich the experience of the sighted students helping diversify perspectives and knowledge by promoting access to explore different senses that would not be taken into consideration in a regular classroom. Besides examining teachers' attitudes towards the visually impaired student and demonstrating the value of a project-based approach, this paper aims to raise awareness of teaching challenges and the VIP contribution to the classroom as they increasingly become students in general education. This paper argues that mainstreaming is beneficial to the visually impaired student as well as the entire class in an inquiry-based environment. [6] suggests that students with disabilities seem to thrive in inquiry-oriented learning environments. The paper promotes inclusive education involving project-based assignments. This form of assignment brings real world problems to the classroom that may be an important factor in guaranteeing the success and acceptance of the visually impaired. The emphasis of creating an opportunity to employ personal knowledge facilitates meaningfulness of the content material. This done by active participation and exploration, building a teaching model based on students' prior experiences and knowledge [7].

In addition, teachers as well as the students' positive attitudes towards inclusion and expectations may provide higher level of academic success. Indeed, [8] reports that teachers' positive attitude towards students with special needs increases selfperception and academic performance. Dubis (1987) surveyed 373 special education teachers' attitudes toward student blindness and identified positive attitudes in general. According to Magdalena, in order to teach statistics to a VIP student three conditions have to be met: 1- an individual approach towards the student, 2- adaptation of didactic materials, and 3-availability of special software such as SPSS (JAWS -Job Access With Speech). The key element of the Americans with Disability Act and Rehabilitation Act of 1973 is creating equal access to people with disabilities. This means to create an environment that will allow an increase in the numbers of pupils that enter higher education. According to research by [9] access is an important element when it comes to inclusion, and inclusion in this context is defined to be more than placement of the special student in a certain setting. When a student with visual impairment is placed in a regular classroom, in a facility that provides access, it does not necessary mean that the student will feel included [9] Students with visual impairment will only be included once their specific and unique educational needs for access are met. This requires the assistance of personnel that are specifically trained for that purpose in a case by case basis.

\section{Methodology}

The teaching model approach of this study to serve the visually impaired student, was based on project-based learning in an inquiry-based framework. The assignment was selected considering the student's motivation and knowledge complying with his personal experience. The assignment included dialectical discussions involving other students and instructors by use of brainstorming sessions. This was an appealing strategy because, instead of reading and or hearing concepts, the student actually used the field of study of his interest to solve real world problems. In this sense, the project-based approach was a powerful tool especially for the visually impaired student as it provided an opportunity for strengthening interactions and contribution with other students and faculty. Because it is important to offer equal opportunity to all learners in the formal education system, it is vital to offer equal opportunities to people with visual impairment in order to ensure that they are able to participate just like any other student in the formal education sector. However, it is imperative to understand how the influence of instructors' attitudes towards students with visually impairment and the associated preparedness of the instructor impact the visually impaired student learning outcomes. The study utilized a mixed-method approach integrating qualitative and quantitative research. The study was conducted online, and participants were provided with the address for the survey monkey website to complete the questionnaire at a time that was convenient for them. The survey was launched on December 1st 2014 and results were compiled on January 14th, 2015. All faculty members of Woodbury University were selected to participate in the study, a total of 120 members. However only 64 faculty chose to participate. The name of participants was not disclosed to protect their confidentiality, but their age, years teaching and exposure to visually impaired people were recorded.

The instrument was created as a group-activity using student peer participation and input from two professors. The questionnaire sought to obtain the following information by dichotomous variables to identify teacher's age, years of teaching, experience teaching visually impaired students and previous interaction with visually impaired people. This was followed by Likert-scale type questions as described in Table 1. At the end of the survey, six openended questions were included. They were intended to encourage respondents to give more information and express themselves. This was done in an effort to reveal attitudes, opinions and beliefs. The following open-ended six questions were analyzed:

I. What is your opinion of a visually impaired person in terms of contributing effectively in the workplace?

II. The office of student development contacts you to let you know that you have a VIP student in one of your courses next semester. How would that affect your lesson plan? (Refer to learning outcomes and lesson plan alterations).

III. Do you think you are prepared to teach a VIP student? 
IV. What do you think the challenges would be to teach a visually impaired student?

V. What are your expectations from the VIP student in terms of participation in class?

VI. Do you think VIP student should be included in regular classes?

\section{Results and Discussion}

The histogram of the Likert scale total mean distribution seems slightly above neutrality. However $22 \%$ of the faculty members interviewed had previous exposure to visually impaired people. The distribution paneled by having or not having past teaching experience of visually impaired students seems to indicate a difference in the distribution with a shift towards higher scores for those faculty that indicated previous experience with visually impaired students (Figure 1). Two outliers were identified and carefully analyzed. They have answered many statements with N/A and were found impractical to the study and were eliminated.
Table 1 displays descriptive statistics of the Likert scale for corresponding scores of the 64 faculty participants, including the percentage distribution of responses, mean per statement, and the last column showing the correlation ( $\mathrm{ri}-\mathrm{t}$ ) of all faculty responses between the score of each individual statement and their overall mean score for all 20 statements (Item-total correlations). This correlation helps to evaluate how well the statement performed in comparison to other statements. Most correlation values were above 0.3 except statements Q10, Q14 and QF20 that had negative values. Considering the rule that correlations between 0.2 and 0.39 indicate good discrimination and for values above 0.4 indicate very good discrimination, Table 1 indicates that $65 \%$ of the statements have positive above 0.4 values implying a very good discrimination, and $20 \%$ of statements between 0.3 and 0.4 implying good discrimination. Generally negative values as encountered on statements Q10, Q14 and Q20 are unexpected because participants that have high scores on the questions should have high scores overall. However, this may also indicate a mis-keyed statement or that the statement was ambiguous and confusing to participants.

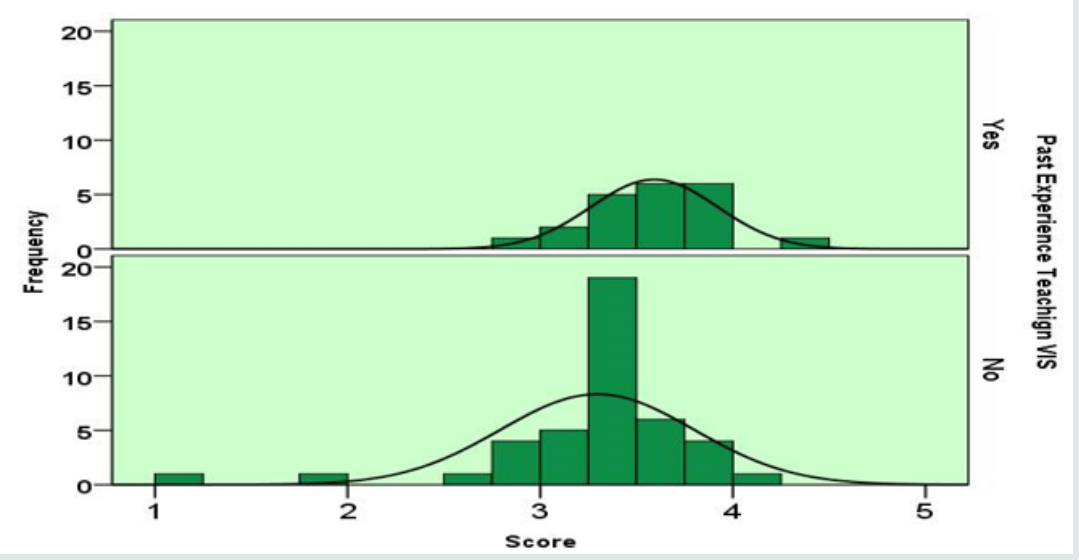

Figure 1: Distribution Score of Teachers with and without past experience with Visually Impaired Students.

Table 1: Likert-scale statements named by Q1-20. Scores are represented accordingly.

\begin{tabular}{|c|c|c|c|c|c|c|c|c|c|}
\hline & Statement Item & $\begin{array}{l}\text { Strongly } \\
\text { Agree }\end{array}$ & Agree & Neutral & Disagree & $\begin{array}{l}\text { Strongly } \\
\text { Disagree }\end{array}$ & N/A & $\begin{array}{l}\text { Item Mean } \\
\text { Score }\end{array}$ & ri-t \\
\hline Q1 & $\begin{array}{l}\text { I feel confident that I will be able to } \\
\text { teach a VIP student }\end{array}$ & $5(25.8 \%)$ & $4(37.1 \%)$ & $3(14.5 \%)$ & $2(14.5 \%)$ & $1(4.8 \%)$ & $0(3.2 \%)$ & 3.61 & 0.62 \\
\hline Q2 & $\begin{array}{l}\text { Blindness is tragically a disabling } \\
\text { condition that negatively will impact } \\
\text { academic success }\end{array}$ & $1(1.6 \%)$ & $2(3.1 \%)$ & $3(10.9 \%)$ & $4(40.6 \%)$ & $5(40.6 \%)$ & $0(1.6 \%)$ & 4.19 & 0.66 \\
\hline Q3 & $\begin{array}{l}\text { I am concerned that the presence of } \\
\text { VIS will impact the class progress } \\
\text { because visual activities have to be } \\
\text { avoided }\end{array}$ & $1(0 \% 0$ & $2(9.4 \%)$ & $3(18.8 \%)$ & $4(40.6 \%)$ & $5(23.4 \%)$ & $0(7.8 \%)$ & 3.85 & 0.67 \\
\hline Q4 & $\begin{array}{l}\text { It would be difficult to alter my } \\
\text { lesson plan involving visual } \\
\text { information if I have a VIP student in } \\
\text { my regular class. }\end{array}$ & $1(4.7 \%)$ & $2(21.9 \%)$ & $3(23.4 \%)$ & $4(25 \%)$ & $5(20.3 \%)$ & $0(4.7 \%)$ & 3.36 & 0.61 \\
\hline Q5 & $\begin{array}{l}\text { I feel uneasy when I have to talk to a } \\
\text { VIP student }\end{array}$ & $1(1.6 \%)$ & $2(0 \%)$ & $3(7.8 \%)$ & $4(28.1 \%)$ & $5(59.4 \%)$ & $0(1.6 \%)$ & 4.48 & 0.30 \\
\hline Q6 & $\begin{array}{l}\text { If I have a VIP student in my class, } \\
\text { I would not slow down the class so } \\
\text { other students do not get bored. }\end{array}$ & $1(3.1 \%)$ & $2(34.4 \%)$ & $3(23.4 \%)$ & $4(15.6 \%)$ & $5(12.5 \%)$ & $0(7.8 \%)$ & 3.00 & 0.40 \\
\hline
\end{tabular}




\begin{tabular}{|c|c|c|c|c|c|c|c|c|c|}
\hline Q7 & $\begin{array}{l}\text { I believe that having a VIP student } \\
\text { in my regular class will affect } \\
\text { negatively other students. }\end{array}$ & $1(0 \%)$ & $2(1.6 \%)$ & $3(4.7 \%)$ & $4(35.9 \%)$ & $5(50 \%)$ & $0(3.1 \%)$ & 4.46 & 0.67 \\
\hline Q8 & $\begin{array}{l}\text { The extra attention VIP student } \\
\text { require will be to the detriment of } \\
\text { other students. }\end{array}$ & $1(1.6 \%)$ & $2(1.6 \%)$ & $3(6.3 \%)$ & $4(39.1 \%)$ & $5(45.3 \%)$ & $0(1.6 \%)$ & 4.33 & 0.72 \\
\hline Q9 & $\begin{array}{l}\text { I believe VIP student have a good } \\
\text { imagination that makes them } \\
\text { understand the main point quickly. }\end{array}$ & $5(9.4 \%)$ & $4(12.5 \%)$ & $3(51.6 \%)$ & $2(6.3 \%)$ & $1(3.1 \%)$ & $0(15.6 \%)$ & 3.23 & 0.37 \\
\hline Q10 & $\begin{array}{l}\text { I believe that if I have a VIP student } \\
\text { in my class, I will have to put } \\
\text { more effort to have extra teaching } \\
\text { materials. }\end{array}$ & $5(10.9 \%)$ & $4(56.3 \%)$ & $3(7.8 \%)$ & $2(14.1 \%)$ & $1(7.8 \%)$ & $0(3.15)$ & 3.50 & -0.25 \\
\hline Q11 & $\begin{array}{l}\text { I believe that the presence of VIP } \\
\text { student in a regular class enhances } \\
\text { learning experiences for other } \\
\text { students. }\end{array}$ & $5(25 \%)$ & $4(34.4 \%)$ & $3(34.4 \%)$ & $2(4.7 \%)$ & $1(0 \%)$ & $0(1.6 \%)$ & 3.81 & 0.45 \\
\hline Q12 & $\begin{array}{c}\text { I think VIP student have a hard time } \\
\text { to adapt themselves in a regular } \\
\text { class. }\end{array}$ & $1(0 \%)$ & $2(7.8 \%)$ & $3(43.8 \%)$ & $4(23.4 \%)$ & $5(14.1 \%)$ & $0(9.4 \%)$ & 3.49 & 0.64 \\
\hline Q13 & $\begin{array}{l}\text { I think VIP student need extra time } \\
\text { to study and do their test then the } \\
\text { sighted student. }\end{array}$ & $5(4.7 \%)$ & $4(25 \%)$ & $3(32.8 \%)$ & $2(20.3 \%)$ & $1(4.7 \%)$ & $0(10.9 \%)$ & 3.02 & 0.39 \\
\hline Q14 & $\begin{array}{l}\text { I believe VIP student require special } \\
\text { materials to make them learn } \\
\text { effectively }\end{array}$ & $5(7.8 \%)$ & $4(53.1 \%)$ & $3(23.4 \%)$ & $2(6.3 \%)$ & $1(3.1 \%)$ & $0(6.3 \%)$ & 3.60 & -0.16 \\
\hline Q15 & $\begin{array}{l}\text { I believe VIP student have a hard } \\
\text { time learning math and writing. }\end{array}$ & $1(0 \%)$ & $2(0 \%)$ & $3(29.7 \%)$ & $4(25 \%)$ & $5(34.4 \%)$ & $0(9.4 \%)$ & 4.05 & 0.49 \\
\hline Q16 & $\begin{array}{l}\text { I would treat my VIP student as any } \\
\text { other student in class. }\end{array}$ & $5(18.8 \%)$ & $4(37.5 \%)$ & $3(18.8 \%)$ & $2(18.8 \%)$ & $1(0 \%)$ & $0(4.7 \%)$ & 3.60 & 0.42 \\
\hline Q17 & $\begin{array}{l}\text { I would not show videos in the } \\
\text { class because VIP student would } \\
\text { not be able to catch up with the } \\
\text { information. }\end{array}$ & $1(0 \%)$ & $2(3.1 \%)$ & $3(15.6 \%)$ & $4(51.6 \%)$ & $5(21.9 \%)$ & $0(6.3 \%)$ & 4.00 & 0.29 \\
\hline Q18 & $\begin{array}{l}\text { I believe VIP student usually lacks } \\
\text { study skills. }\end{array}$ & $1(0 \%)$ & $2(0 \%)$ & $3(9.4 \%)$ & $4(18.8 \%)$ & $5(67.2 \%)$ & $0(3.1 \%)$ & 4.61 & 0.55 \\
\hline Q19 & $\begin{array}{c}\text { I feel that I don't want to teach VIP } \\
\text { student because it requires more } \\
\text { effort. }\end{array}$ & $1(0 \%)$ & $2(4.7 \%)$ & $3(12.5 \%)$ & $4(25 \%)$ & $5(53.1 \%)$ & $0(3.1 \%)$ & 4.33 & 0.54 \\
\hline Q20 & $\begin{array}{l}\text { I believe that I need to attend special } \\
\text { training to teach VIP student. }\end{array}$ & $5(9.4 \%)$ & $4(45.3 \%)$ & $3(25 \%)$ & $2(14.1 \%)$ & $1(4.7 \%)$ & $0(1.6 \%)$ & 3.41 & -0.14 \\
\hline
\end{tabular}

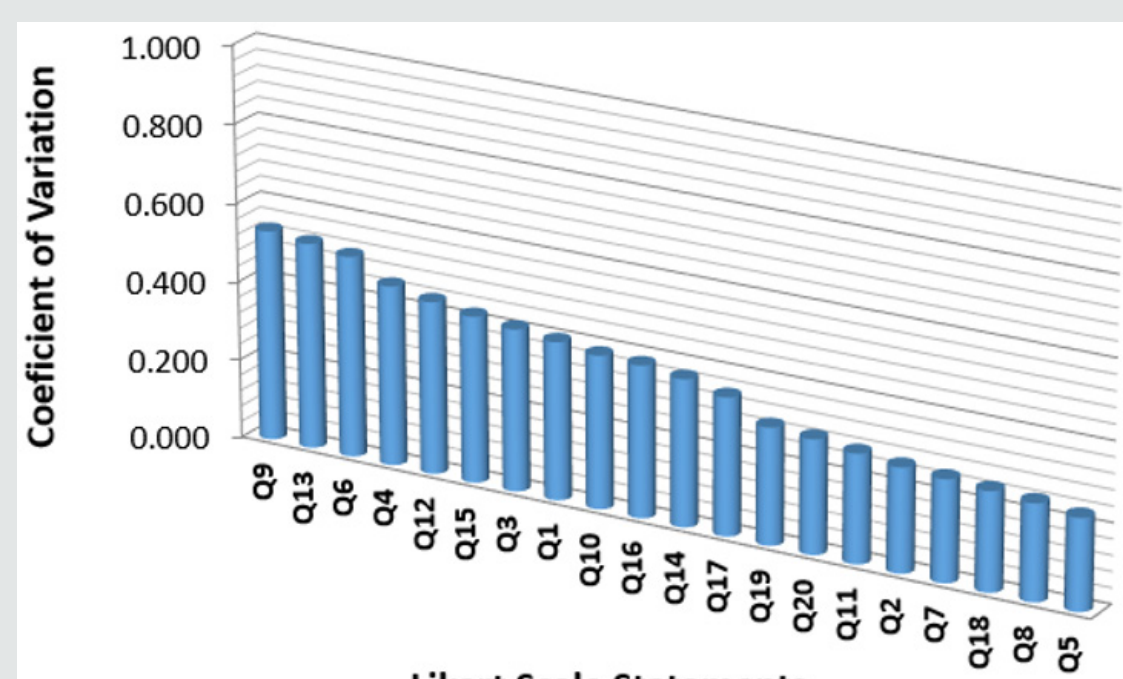

Likert Scale Statements

Figure 2: Coefficient of Variation from Likert Scale Statements. 
Forty percent (40\%) of the Likert scale statements score a mean of 4 and above. The percentage distribution for the responses to each of the 20 statements shown in Table 1 indicate that faculty, overall, responded with a positive attitude towards the teaching experience of a visually impaired student. This was especially true for the statements with higher scores and item-total correlations such as Q7 (I believe that having a VIP student in my regular class will affect negatively other students) and Q8 (The extra attention VIP student require will be to the detriment of other students). In contrast to neutral statements Q6 (If I have a VIP student in my class, I would not slow down the class so other students do not get bored) and Q13 (I think VIP student need extra time to study and do their test then the sighted student) were evenly distributed (Figure 2).

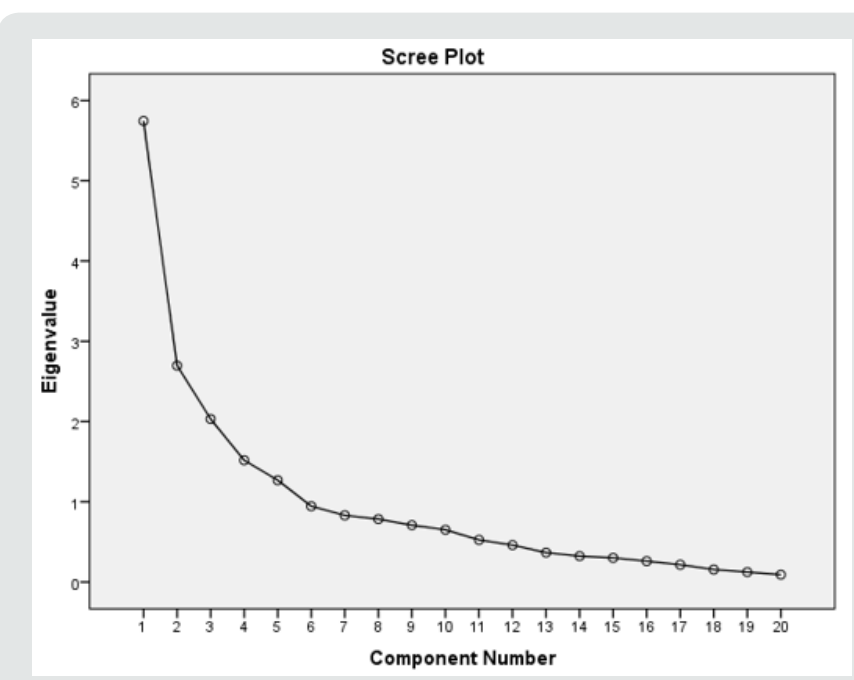

Figure 3: Scree Plot.

The lowest item mean scores were obtained by the statements Q6 (If I have a VIP student in my class, I would not slow down the class so other students do not get bored), Q9 (I believe that VIP student have good imagination that makes them understand the main point quickly) and Q13 (I think VIP student need extra time to study and to do their test then the normal student) indicating most faculty believe that VIP student will slow down the class and they will need more time to learn. These statements have also the highest coefficients of variation as shown in Figure 3 indicating high variability. The coefficient of variation (CV) is defined as the ratio of the standard deviation by the mean to measure relative variation of the data. Higher values mean higher variability. Another possible explanation for lowest item mean score and higher coefficient of variation is that many respondents that had no past experience with VIP people selected N/A, avoiding a response to the statement. This may be evidence of bias disability, refusing to admit that they believe that VIS do not have a good imagination. This may indicate that faculty with no experience teaching visually impaired students have a negative attitude towards the VIP student because they believe the presence of a VIP student would require the class to slow down and would impact negatively the class by having other students bored. In contrast the following statements have the lowest variability and highest scores: Q5 (I feel uneasy when I have to talk with a VIP student), Q18 (I believe the VIS lacks study skills) and Q8 (The extra attention VIP student require will be to the detriment of other students.) show a positive attitude towards teachers confidence to approach the VIS, student's sufficient study skills, as well as the enrichment to the class experience by pointing to the fact the blindness is not an impairment to academic success Figure 4.

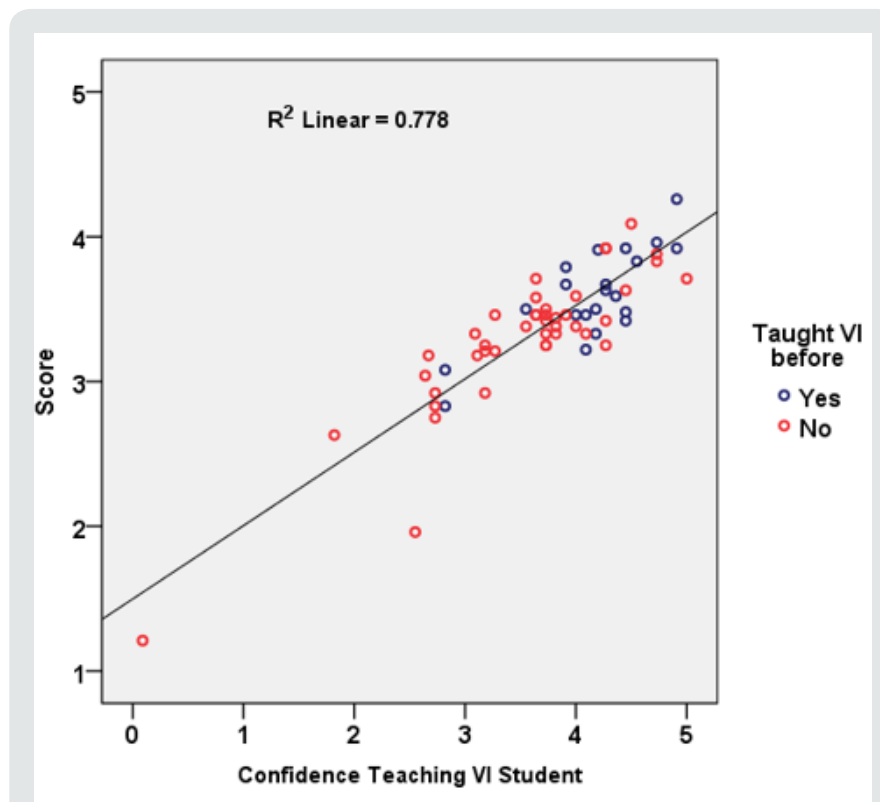

Figure 4: Scree Plot.

Independent t-tests were performed for all statements in regard to faculty with and without past experience with visually impaired people. Nine of the statements indicated a significant difference between faculty attitude towards teaching the VIP student as shown in Tables $2 \& 3$. The results of independent $t$-test revealed that teachers with teaching VIP experience generally had positive attitudes toward VIP students with respect to statements Q1, Q2, Q3, Q4, Q6, Q7, Q9, Q17, and Q20 showed significant difference between teachers with and without past experience teaching the visually impaired. It seems that most significant differences between teachers with and without past experience teaching the VIP student are related to confidence in the teacher's ability to teach the visually impaired, the belief that the inclusion of the VIP student in a regular class will affect negatively the progress, the difficulty to alter lesson plan and the abilities of the VIS to understand the main point of the lesson. It is interesting to note that statement Q20 (I believe that I need to attend special training to teach VIP student) referring to training had low a score for those teachers with previous experience with VIP student. It is in contrast to those teachers that did not have experience with the VIP and admitted that they do need training. Training and having previous experience teaching the VIP student were identified as influential factors regarding positive teachers' attitude. Because the survey is based on a Likert scale generating ordinal data, with categorical independent data and independence of observations of a non-normal distribution, it was advisable to test Mann-Whitney U Wilcoxon for independence, as shown in Table 4. Results show significant difference for the 
same statements as observed by independent t-test indicating internal consistence reliability. Cronbach's alpha value, associated with all 20 statements scores, indicates a respectable 0.830 , as shown in Table 5, suggesting that the items have good internal consistency. Consequently, the high Cronbach's alpha value means it is justifiable to interpret the 20 items' scores as an aggregated, according to the level of reliability criteria provided by [10] , described in Table 6 . The set of 20 statements provides internal consistency and deleting any statement will have a negligible impact on the alpha, as described in last column of Table 7 (Itemtotal Cronbach's statistics). Statement Q20, if removed, would slightly improve Cronbach's coefficient to 0.843. In addition, it is the only statement to indicate negative item-total correlation possibly because this statement had lower scores for faculty with VIS teaching experience than for the without as was shown in Table 2. In addition, in Table 8, for Cronbach's Alpha Inter -total correlation, statement Q20 shows a negative correlation. A possible cause for the negative correlation could be that a higher score was attributed to those that agree to have training to better attend the needs of the VIP student. Most faculty that did not have experience teaching the VIP strongly agree that training would be necessary. This demonstrates their interest in improving teaching skills, while teachers with past experience stated that they did not need training, thus lowering their scores. For the purpose of correlation analysis, color-coded data was utilized according to the rule of thumb defined by [11] categorization (Table 8). According to Table $930 \%$ of the correlation were in the weak category represented by the orange color, followed by $19 \%$ moderate strength of correlation represented in blue. Only one correlation was strong, given in yellow. Its value was 0.749 correlation between Q7 and Q8. This result was observed possibly because both statements have similar meaning [11-14]. It shows most of the respondents strongly disagree that the VIP student will affect negatively other students because of instructor's extra attention to the VIP student. Represented in pink are $18 \%$ of the negative correlations. Table 9 indicates that most negative correlations are obtained for statement Q20. A possible cause for the negative correlation could be that a higher score was attributed to those that agree to have training to better attend the needs of the VIS. Most faculty that did not have experience teaching strongly agree that training would be necessary, demonstrating interest in improving their teaching skills. In addition, the fact that some faculty responded N/A to some statements - at most $15.6 \%$ of respondents for statement $Q 9$, may be a possible cause for the negative correlation. Moreover, taking into consideration that this exploratory study has a relatively small sample size, as the data is strongly affected by a few respondents, may also have contributed for negative correlations. The fact that many other items showed a positive association, above 0.20 (50\% of the cases), and that Cronbach's alpha is 0.830 indicates an acceptable internal consistency. While 0.830 indicates good internal consistency, it does not mean that the scale is unidimensional. In order to determine dimensionality, a scaled factor analysis was performed [14-19].

Table 2: Descriptive statistics of statements.

\begin{tabular}{|c|c|c|c|c|c|}
\hline \multicolumn{6}{|c|}{ Group Statistics } \\
\hline & Past & $\mathrm{N}$ & Mean & $\begin{array}{c}\text { Std. } \\
\text { Deviation }\end{array}$ & $\begin{array}{c}\text { Std. Error } \\
\text { Mean }\end{array}$ \\
\hline \multirow{2}{*}{ Q1 } & Yes & 21 & 4.29 & 0.784 & 0.171 \\
\hline & No & 40 & 3.18 & 1.412 & 0.223 \\
\hline \multirow{2}{*}{ Q2 } & Yes & 21 & 4.52 & 0.602 & 0.131 \\
\hline & No & 41 & 3.93 & 1.149 & 0.179 \\
\hline \multirow{2}{*}{ Q3 } & Yes & 21 & 4.29 & 0.561 & 0.122 \\
\hline & No & 42 & 3.17 & 1.513 & 0.233 \\
\hline \multirow{2}{*}{ Q4 } & Yes & 21 & 3.71 & 1.146 & 0.25 \\
\hline & No & 42 & 2.95 & 1.431 & 0.221 \\
\hline \multirow{2}{*}{ Q5 } & Yes & 21 & 4.57 & 0.598 & 0.13 \\
\hline & No & 41 & 4.34 & 1.109 & 0.173 \\
\hline \multirow{2}{*}{ Q6 } & Yes & 21 & 3.29 & 1.271 & 0.277 \\
\hline & No & 40 & 2.48 & 1.358 & 0.215 \\
\hline \multirow{2}{*}{ Q7 } & Yes & 20 & 4.75 & 0.55 & 0.123 \\
\hline & No & 40 & 4.1 & 1.172 & 0.185 \\
\hline \multirow{2}{*}{ Q8 } & Yes & 21 & 4.52 & 0.75 & 0.164 \\
\hline & No & 40 & 4.13 & 1.067 & 0.169 \\
\hline \multirow{2}{*}{ Q9 } & Yes & 21 & 3.24 & 1.338 & 0.292 \\
\hline & No & 41 & 2.44 & 1.45 & 0.226 \\
\hline \multirow{2}{*}{ Q10 } & Yes & 21 & 3.29 & 1.231 & 0.269 \\
\hline & No & 42 & 3.45 & 1.31 & 0.202 \\
\hline \multirow{2}{*}{ Q11 } & Yes & 21 & 3.9 & 0.944 & 0.206 \\
\hline & No & 42 & 3.69 & 1.024 & 0.158 \\
\hline \multirow{2}{*}{ Q12 } & Yes & 21 & 3.57 & 1.248 & 0.272 \\
\hline & No & 41 & 2.95 & 1.341 & 0.209 \\
\hline \multirow{2}{*}{ Q13 } & Yes & 21 & 2.76 & 1.136 & 0.248 \\
\hline & No & 41 & 2.68 & 1.457 & 0.227 \\
\hline \multirow{2}{*}{ Q14 } & Yes & 21 & 3.57 & 1.165 & 0.254 \\
\hline & No & 42 & 3.29 & 1.255 & 0.194 \\
\hline \multirow{2}{*}{ Q15 } & Yes & 21 & 3.71 & 1.454 & 0.317 \\
\hline & No & 41 & 3.73 & 1.361 & 0.212 \\
\hline \multirow{2}{*}{ Q16 } & Yes & 21 & 3.81 & 1.123 & 0.245 \\
\hline & No & 41 & 3.24 & 1.319 & 0.206 \\
\hline \multirow{2}{*}{ Q17 } & Yes & 21 & 4.24 & 0.539 & 0.118 \\
\hline & No & 41 & 3.49 & 1.399 & 0.218 \\
\hline \multirow{2}{*}{ Q18 } & Yes & 21 & 4.38 & 1.203 & 0.263 \\
\hline & No & 41 & 4.51 & 0.978 & 0.153 \\
\hline \multirow{2}{*}{ Q19 } & Yes & 21 & 4.48 & 0.873 & 0.19 \\
\hline & No & 41 & 4.05 & 1.284 & 0.2 \\
\hline \multirow{2}{*}{ Q20 } & Yes & 21 & 2.95 & 1.203 & 0.263 \\
\hline & No & 42 & 3.55 & 0.993 & 0.153 \\
\hline
\end{tabular}


Table 3: Independent t-test of statements comparing faculty with and without past experience teaching VIS

\begin{tabular}{|c|c|c|c|c|c|c|c|c|c|c|}
\hline \multicolumn{11}{|c|}{ Independent Samples Test } \\
\hline & & \multicolumn{2}{|c|}{ Equalityof Varian ces } & \multicolumn{7}{|c|}{ t-test for Equalityof Means } \\
\hline & & \multirow[b]{2}{*}{$F$} & \multirow[b]{2}{*}{ Sig. } & \multirow[b]{2}{*}{$t$} & \multirow[b]{2}{*}{ df } & \multirow{2}{*}{$\begin{array}{c}(2- \\
\text { tailed) }\end{array}$} & \multirow{2}{*}{$\begin{array}{c}\text { Mean } \\
\text { Difierence }\end{array}$} & \multirow{2}{*}{$\begin{array}{l}\text { Std. Error } \\
\text { Differen ce }\end{array}$} & \multicolumn{2}{|c|}{$95 \%$ Confidence Interval } \\
\hline & & & & & & & & & Lower & Upper \\
\hline \multirow{2}{*}{ Q1 } & Equal va rian ces as sumed & 9.542 & 0.003 & 3.336 & 59 & 0.001 & 1.111 & 0.333 & 0.445 & 1.777 \\
\hline & Equal variances notassumed & & & 3.949 & 59 & 0.000 & 1.111 & 0.281 & 0.548 & 1.874 \\
\hline \multirow{2}{*}{ Q2 } & Equal va riances as sumed & 1.852 & 0.179 & 2.224 & 60 & 0.030 & 0.597 & 0.288 & 0.060 & 1.134 \\
\hline & Equal variances notassumed & & & 2.685 & 60 & 0.009 & 0.597 & 0.222 & 0.152 & 1.042 \\
\hline \multirow{2}{*}{ Q3 } & Equal va riances as sumed & 11.135 & 0.001 & 3.288 & 61 & 0.002 & 1.119 & 0.342 & 0.434 & 1.804 \\
\hline & Equal variances notassumed & & & 4.246 & 58 & 0.000 & 1.119 & 0.284 & 0.591 & 1.647 \\
\hline \multirow{2}{*}{ Q4 } & Equal varian ces as sumed & 2.668 & 0.108 & 2.121 & 61 & 0.038 & 0.762 & 0.359 & 0.044 & 1.480 \\
\hline & Equal variances notassumed & & & 2.284 & 49 & 0.027 & 0.762 & 0.334 & 0.091 & 1.432 \\
\hline \multirow{2}{*}{ Q5 } & Equal variances as sumed & 2.577 & 0.114 & 0.884 & 60 & 0.380 & 0.230 & 0.260 & -0290 & 0.750 \\
\hline & Equal variances notassumed & & & 1.061 & 60 & 0.293 & 0.230 & 0.217 & -02204 & 0.684 \\
\hline \multirow{2}{*}{ C6 } & Equal va riances as sumed & 0.006 & 0.938 & 2.263 & 59 & 0.027 & 0.811 & 0.358 & 0.094 & 1.528 \\
\hline & Equal varian ces notassumed & & & 2.312 & 43 & 0.026 & 0.811 & 0.351 & 0.104 & 1.518 \\
\hline \multirow{2}{*}{ Q7 } & Equal va riances as sumed & 2236 & 0.140 & 2.346 & 58 & 0.022 & 0.850 & 0.277 & 0.095 & 1205 \\
\hline & Equal variances notassumed & & & 2.922 & 58 & 0.005 & 0.650 & 0.222 & 0.205 & 1.095 \\
\hline \multirow{2}{*}{ Q8 } & Equal variances as sumed & 0.345 & 0.559 & 1.524 & 59 & 0.133 & 0.399 & 0.262 & -0.125 & 0.922 \\
\hline & Equal variances notassumed & & & 1.697 & 54 & 0.095 & 0.399 & 0.235 & -0.072 & 0.870 \\
\hline \multirow{2}{*}{$Q 9$} & Equal variances as sumed & 1.499 & 0226 & 2.106 & 60 & 0.039 & 0.799 & 0.379 & 0.040 & 1.558 \\
\hline & Equal va rian ces not assumed & & & 2.162 & 43 & 0.036 & 0.799 & 0.370 & 0.054 & 1.544 \\
\hline \multirow{2}{*}{ Q10 } & Equal va riances as sumed & 0.001 & 0.977 & -0.485 & 61 & 0.629 & -0.187 & 0.343 & -0.853 & 0.520 \\
\hline & Equal variances notassumed & & & -0.496 & 42 & 0.623 & -0.167 & 0.336 & -0.845 & 0.511 \\
\hline \multirow{2}{*}{ Q11 } & Equal va riances as sumed & 0.443 & 0.508 & 0.803 & 61 & 0.425 & 0214 & 0.287 & -0.319 & 0.748 \\
\hline & Equal variances notassumed & & & 0.826 & 43 & 0.414 & 0214 & 0.260 & -0.309 & 0.738 \\
\hline & Equal va riances as sumed & 0.179 & 0.674 & 1.764 & 60 & 0.083 & 0.620 & 0.352 & -0.083 & 1.324 \\
\hline Q12 & Equal variances notassumed & & & 1.806 & 43 & 0.078 & 0.620 & 0.344 & -0.072 & 1.313 \\
\hline 013 & Equal va riances as sumed & 2.839 & 0.097 & 0.217 & 60 & 0.829 & 0.079 & 0.384 & -0.650 & 0.808 \\
\hline 013 & Equal va riances notassumed & & & 0.235 & 50 & 0.815 & 0.079 & 0.336 & -0.597 & 0.755 \\
\hline & Equal varian ces as sumed & 0.172 & 0.679 & 0.872 & 61 & 0.387 & 0.286 & 0.328 & -0.370 & 0.941 \\
\hline Q14 & Equal variances notassumed & & & 0.894 & 43 & 0.376 & 0.286 & 0.320 & -0.359 & 0.930 \\
\hline 015 & Equal va riances as sumed & 0.000 & 0.994 & -0.047 & 60 & 0.963 & -0.017 & 0.374 & -0.785 & 0.730 \\
\hline Q15 & Equal variances notassumed & & & -0.046 & 38 & 0.964 & -0.017 & 0.382 & -0.790 & 0.756 \\
\hline 018 & Equal variances as sumed & 3.523 & 0.065 & 1.677 & 60 & 0.099 & 0.568 & 0.337 & -0.109 & 1240 \\
\hline 010 & Equal variances notassumed & & & 1.767 & 47 & 0.084 & 0.568 & 0.320 & -0.079 & 1210 \\
\hline & Equal va riances as sumed & 8.519 & 0.005 & 2.362 & 60 & 0.021 & 0.750 & 0.318 & 0.115 & 1.386 \\
\hline 017 & Equal variances notassumed & & & 3.024 & 57 & 0.004 & 0.750 & 0.248 & 0.254 & 1247 \\
\hline 018 & Equal variances as sumed & 0.457 & 0.501 & -0.462 & 60 & 0.646 & -0.131 & 0.284 & -0.699 & 0.437 \\
\hline Q18 & Equal va riances notassumed & & & -0.432 & 34 & 0.668 & -0.131 & 0.304 & -0.749 & 0.486 \\
\hline 010 & Equal va riances as sumed & 1234 & 0271 & 1.370 & 60 & 0.176 & 0.427 & 0.312 & -0.197 & 1.052 \\
\hline 019 & Equal varian ces not assumed & & & 1.546 & 55 & 0.128 & 0.427 & 0.277 & -0.127 & 0.982 \\
\hline & Equal varian ces as sumed & 2297 & 0.135 & -2.089 & 61 & 0.041 & -0.595 & 0.285 & -1.165 & -0.025 \\
\hline 020 & Equal va rian ces notassumed & & & -1.958 & 34 & 0.058 & -0.595 & 0.304 & -1213 & 0.022 \\
\hline
\end{tabular}

Table 4: Mann-Whitney U Wilcoxon W

\section{Test Statistics ${ }^{\mathrm{a}}$}

\begin{tabular}{|c|c|c|c|c|c|c|c|c|c|c|c|c|c|c|c|c|c|c|c|c|}
\hline Mann-WhitneyU & 221 & 298 & 236 & 292 & 410 & 290 & 241 & 317 & 296 & 399 & 386 & 309 & 402 & 384 & 423 & 318 & 293 & 412 & 348 & 306 \\
\hline Wilcoxon W & 1041 & 1159 & 1139 & 1195 & 1271 & 1110 & 1061 & 1137 & 1157 & 630 & 1289 & 1170 & 633 & 1287 & 1284 & 1179 & 1154 & 643 & 1209 & 537 \\
\hline Z & -3.144 & -2.126 & -3.131 & -2.225 & -0.361 & -2.050 & -2.798 & -1.723 & -2.171 & -0.681 & -0.851 & -1.914 & -0.438 & -0.912 & -0.117 & -1.750 & -2.231 & -0.348 & -1.356 & -2.084 \\
\hline Asymp. Sig. (2-tailed) & 0.002 & 0.034 & 0.002 & 0.026 & 0.718 & 0.040 & 0.005 & 0.085 & 0.030 & 0.496 & 0.395 & 0.056 & 0.662 & 0.362 & 0.907 & 0.080 & 0.026 & 0.728 & 0.175 & 0.037 \\
\hline
\end{tabular}


Table 5: Cronbach's Alpha for all 20 statements.

\begin{tabular}{|c|c|c|}
\hline \multicolumn{2}{|c|}{ Reliability Statistics } \\
\hline Cronbach's Alpha & Cronbach's Alpha Based on Standardized Items & N of Items \\
\hline 0.830 & 0.834 & 20 \\
\hline
\end{tabular}

Table 6: Acceptable Level of reliability (George \& Malley, 2003).

\begin{tabular}{|c|c|c|}
\hline $\mathrm{a}$ & $>0.90$ & Excellent \\
\hline $\mathrm{b}$ & $0.80-0.89$ & Good \\
\hline $\mathrm{c}$ & $0.70-0.79$ & Acceptable \\
\hline $\mathrm{d}$ & $0.60-0.69$ & Questionable \\
\hline $\mathrm{e}$ & $0.50-0.59$ & Poor \\
\hline $\mathrm{f}$ & $<0.50$ & Unacceptable \\
\hline
\end{tabular}

Table 7: Item-total Cronbach's Alpha Statistics.

\begin{tabular}{|c|c|c|c|c|c|}
\hline \multicolumn{6}{|c|}{ Item-Total Statistics } \\
\hline & $\begin{array}{c}\text { Scale Mean if Item } \\
\text { Deleted }\end{array}$ & $\begin{array}{c}\text { Scale Variance if Item } \\
\text { Deleted }\end{array}$ & $\begin{array}{c}\text { Corrected Item-Total } \\
\text { Correlation }\end{array}$ & $\begin{array}{c}\text { Squared Multiple } \\
\text { Correlation }\end{array}$ & $\begin{array}{l}\text { Cronbach's Alpha if } \\
\text { Item Deleted }\end{array}$ \\
\hline Q1 & 68.58 & 128.284 & .547 & .797 & .815 \\
\hline Q2 & 68.02 & 137.625 & .328 & .438 & .826 \\
\hline Q3 & 68.63 & 126.523 & .574 & .567 & .813 \\
\hline Q4 & 69.00 & 128.821 & .508 & .637 & .817 \\
\hline Q5 & 67.74 & 133.126 & .560 & .565 & .817 \\
\hline Q6 & 69.39 & 129.920 & .463 & .540 & .819 \\
\hline Q7 & 67.84 & 131.885 & .567 & .755 & .816 \\
\hline Q8 & 67.91 & 132.510 & .583 & .745 & .816 \\
\hline Q9 & 69.49 & 137.683 & .211 & .441 & .833 \\
\hline Q10 & 68.86 & 140.944 & .135 & .551 & .836 \\
\hline Q11 & 68.40 & 138.495 & .303 & .585 & .827 \\
\hline Q12 & 69.04 & 125.213 & .636 & .703 & .810 \\
\hline Q13 & 69.46 & 133.788 & .364 & .546 & .825 \\
\hline Q14 & 68.82 & 133.969 & .385 & .694 & .823 \\
\hline Q15 & 68.44 & 136.108 & .261 & .505 & .830 \\
\hline Q16 & 68.74 & 134.412 & .361 & .539 & .825 \\
\hline Q17 & 68.44 & 136.536 & .294 & .592 & .828 \\
\hline Q18 & 67.70 & 133.784 & .479 & .777 & .820 \\
\hline Q19 & 67.96 & 126.142 & .719 & .671 & .808 \\
\hline Q20 & 68.88 & 147.503 & -.073 & .586 & .843 \\
\hline
\end{tabular}

Table 8: Dancey and Reidy's (2004) correlation categorization.

\begin{tabular}{|c|c|}
\hline Value of the Correlation Coefficient & Strength of Correlation \\
\hline 1 & Perfect \\
\hline $0.7-0.9$ & Strong (yellow) \\
\hline $0.4-0.69$ & Moderate (grey-blue) \\
\hline $0.1-0.39$ & Weak (orange) \\
\hline$<0.1$ & (No fill) \\
\hline Negative correlation & (Pink) \\
\hline
\end{tabular}


Table 9: Inter-item Correlation Matrix.

\begin{tabular}{|c|c|c|c|c|c|c|c|c|c|c|c|c|c|c|c|c|c|c|c|c|}
\hline \multicolumn{21}{|c|}{ Inter-Item Correlation Matrix } \\
\hline & 11 & & 23 & Q4 & $\mathrm{Q} 5$ & Q6 & Q7 & Q8 & Q9 & Q10 & Q11 & Q12 & Q13 & Q14 & Q15 & Q16 & 217 & Q18 & Q19 & $\mathrm{Q} 20$ \\
\hline Q1 & 000 & 299 & 482 & 648 & 406 & 264 & 0.397 & & 331 & -0.232 & & 606 & 234 & 011 & 214 & 0.394 & .010 & .098 & 488 & \\
\hline Q2 & 0.299 & 000 & 086 & 7 & 140 & 252 & 402 & 0 & 058 & & 151 & 268 & -0.134 & 0.119 & 0.280 & 0.107 & .086 & 0.282 & 230 & -0.010 \\
\hline Q3 & 0.482 & 086 & 000 & 477 & 506 & 0.380 & 414 & & 281 & 0.041 & 0.286 & 0.390 & 0.205 & 0.071 & 0.046 & 319 & 0.242 & 0239 & 492 & -0.092 \\
\hline Q4 & 648 & 177 & 477 & 000 & & & & & & & & & & & & & & & & \\
\hline Q5 & 0.406 & 0.140 & .506 & 256 & 1.000 & 0.300 & 372 & & -0.065 & 0.11 & 0.084 & & & 0234 & 0.251 & 0.468 & 0.325 & 0.393 & 0.500 & -0.200 \\
\hline Q6 & 0.264 & 252 & 380 & 238 & 300 & 1.000 & 251 & 283 & 197 & -0.051 & 302 & 464 & 0.291 & 0.273 & 0.105 & 0.121 & & & & 0.118 \\
\hline Q7 & & 402 & 414 & 0.579 & 372 & 0.25 & .000 & & & & 5 & & 0.004 & 45 & 02 & 9 & 0.214 & & & \\
\hline Q8 & 0.495 & 423 & 418 & 0.575 & 374 & 0.283 & 749 & 1.000 & 0.009 & -0.0 & 202 & 0.390 & 0.057 & -0.018 & 0.304 & 0.371 & 0.099 & 0.536 & 0.497 & -0.278 \\
\hline Q9 & 0.331 & 058 & 281 & 316 & .065 & 0.197 & 130 & 0.009 & 1.000 & & 232 & 0.249 & .196 & 0.063 & -0.0 & 0.038 & 26 & & .082 & 0.136 \\
\hline Q10 & .232 & -0.037 & 041 & -0.120 & 114 & -0.051 & 013 & -0.038 & -0.080 & & 137 & & 321 & 0.488 & & & .477 & & & 0.469 \\
\hline Q11 & 0.166 & 0.151 & 0.286 & 0.243 & 0.084 & 0.302 & 0.105 & 0.202 & 0.232 & 0.137 & 1.000 & 0.150 & 0.110 & -0.062 & -0.005 & -0.182 & 0.189 & -0.047 & 423 & 0.339 \\
\hline 12 & 0.606 & 0.268 & 390 & 433 & 335 & 0.464 & 358 & & 249 & -0.08 & 0.150 & 1.000 & 0.177 & & & 0.408 & & 0.4 & 589 & -0.073 \\
\hline Q13 & 0.234 & -0.134 & 205 & 0.114 & 341 & 0.291 & 0.004 & 0.057 & 0.196 & 0.321 & 0.110 & 0.177 & 1.000 & 0.506 & -0.002 & 0.105 & 0.2 & 7 & & 0.175 \\
\hline Q14 & 0.011 & 0.119 & 0.071 & -0.056 & 0.234 & 0.273 & 0.045 & -0.018 & 0.063 & 0.488 & -0.062 & 0.340 & 0.506 & 1.000 & 0.052 & 0.190 & 0.407 & 0.311 & 0.319 & 0.263 \\
\hline Q15 & 0.214 & 0.280 & 046 & 0.232 & 251 & 0.105 & 0.297 & 0.304 & -0.042 & -0.109 & -0.005 & 0.310 & -0.002 & 0.052 & 1.000 & 0.153 & 0.1 & 1 & 0.170 & \\
\hline Q16 & 0.394 & 0.107 & 0.319 & 0.207 & 0.468 & 0.121 & 0.219 & 0.371 & 0.038 & -0.085 & -0.182 & 0.408 & 0.105 & 0.190 & 0.153 & 1.000 & 0.128 & 0.418 & 0.359 & -0.337 \\
\hline Q17 & 0.010 & 0.086 & 0.242 & -0.014 & 0.325 & -0.032 & 0.214 & 0.099 & -0.126 & 0.477 & 0.189 & 0.011 & 0.242 & 0.407 & 0.100 & 0.128 & 1.000 & 0.147 & 0.323 & 0.068 \\
\hline Q18 & 0.098 & 0.282 & 0.239 & 0.243 & 0.393 & 0.138 & 0.552 & 0.536 & -0.122 & 0.083 & -0.047 & 0.425 & 0.057 & 0.311 & 0.541 & 0.418 & 0.147 & 1.000 & 0.424 & -0.177 \\
\hline Q19 & 0.488 & 0.230 & 0.492 & 0.430 & 0.500 & 0.420 & 0.411 & 0.497 & 0.082 & 0.118 & 0.423 & 0.589 & 0.330 & 0.319 & 0.170 & 0.359 & 0.323 & 0.424 & 1.000 & -0.047 \\
\hline Q20 & -0.352 & -0.010 & -0.092 & -0.272 & -0.200 & 0.118 & -0.189 & -0.278 & 0.136 & 0.469 & 0.339 & -0.073 & 0.175 & 0.263 & -0.283 & -0.337 & 0.068 & -0.177 & -0.047 & 1.000 \\
\hline
\end{tabular}

A Principal Components Analysis (PCA) with a Varimax (orthogonal) rotation of the 20 statements was conducted on the data gathered from 62 faculty participants. An examination of the Kaiser-Meyer Olkin measure of sampling adequacy suggests that the sample was factorable $(\mathrm{KMO}=0.685)$ greater than 0.600 indicating satisfactory adequacy as shown in Table 10, considering that above 0.500 usually indicate appropriateness of the factor analysis. In Figure 2 the scree plot is describes each factor indicating that after factor 5 there is a sharp change in curvature of the scree plot. This indicated that after factor 5 the total variance accounts for smaller amounts. In the present study only 4 factors will be extracted by combining the relevant variables together. In the total variance explained Table 11, the Eigen values are the variances of the factors where the total column indicates the Eigenvalues. The most variance and highest Eigen values are observed in the first factor. The next factor will account for additional variance left until the last factor. The percentage of variance represents the percent of the total variance accounted by each factor and the cumulative percentage of the variance account is described. As shown, there is little change from component 4 to $5.0 n$ the basis of Varimax Rotation 4 factor were extracted. Each factor is constructed from 20 variables as shown in Table 12. The four factors extracted explained $59.95 \%$ of the variance as indicated in Table 11. Because the fourth component has only one variable, it was not considered as a factor. According to the grouping, each group was named accordingly as teacher's confidence ability, Impact on lesson's plan, and VIP student's contribution to the class. The five highest scores Q5 (I feel uneasy when I have to talk with a VIP student), Q7(I believe that having a VIP student in my regular class will affect negatively other students), Q8 (The extra attention VIP student require will be to the detriment of other students.), Q18 (I believe the VIP student lacks study skills) and Q19 (I feel that I don't want to teach VIP student because it requires more effort) all belonging to component 1 (Teaching self-confidence in the ability to teach) as demonstrated by factor analysis. Table 13 suggests that faculty with experience teaching the VIP student have higher scores. Independent t-test has however indicated that only Teacher's confidence and Students' contribution factors were significant different. Lesson impact due to the presence of a VIP student in class has a neutral score close to 3 and does not indicate a significant difference between faculty with and without previous experience with VIP student instruction.

Table 10: Inter-item Correlation Matrix.

\begin{tabular}{|c|c|c|}
\hline \multicolumn{2}{|c|}{ KMO and Bartlett's Test } \\
\hline $\begin{array}{c}\text { Kaiser-Meyer-Olkin Measure of Sampling } \\
\text { Adequacy. }\end{array}$ & .685 \\
\hline $\begin{array}{c}\text { Bartlett's Test of } \\
\text { Sphericity }\end{array}$ & Approx. Chi-Square & 539.936 \\
\hline & $\mathrm{df}$ & 190 \\
\hline & Sig. & .000 \\
\hline
\end{tabular}


Table 11: Total variance explained.

\begin{tabular}{|c|c|c|c|c|c|c|c|c|c|}
\hline \multicolumn{10}{|c|}{ Total Variance Explained } \\
\hline \multirow[b]{2}{*}{ Component } & \multicolumn{3}{|c|}{ Initial Eigenvalues } & \multicolumn{3}{|c|}{ Loadings } & \multicolumn{3}{|c|}{ Loadings } \\
\hline & Total & $\begin{array}{c}\% \text { of } \\
\text { Variance }\end{array}$ & Cumulative \% & Total & $\begin{array}{c}\% \text { of } \\
\text { Variance }\end{array}$ & $\begin{array}{c}\text { Cumulative } \\
\%\end{array}$ & Total & $\begin{array}{c}\% \text { of } \\
\text { Variance }\end{array}$ & $\begin{array}{c}\text { Cumulative } \\
\%\end{array}$ \\
\hline 1 & 5.745 & 28.726 & 28.726 & 5.745 & 28.726 & 28.726 & 3.991 & 19.955 & 19.955 \\
\hline 2 & 2.697 & 13.483 & 42.209 & 2.697 & 13.483 & 42.209 & 3.174 & 15.869 & 35.824 \\
\hline 3 & 2.032 & 10.159 & 52.368 & 2.032 & 10.159 & 52.368 & 2.767 & 13.833 & 49.657 \\
\hline 4 & 1.517 & 7.587 & 59.955 & 1.517 & 7.587 & 59.955 & 2.060 & 10.298 & 59.955 \\
\hline 5 & 1.268 & 6.341 & 66.296 & & & & & & \\
\hline 6 & 0.945 & 4.724 & 71.020 & & & & & & \\
\hline 7 & 0.831 & 4.153 & 75.172 & & & & & & \\
\hline 8 & 0.784 & 3.920 & 79.093 & & & & & & \\
\hline 9 & 0.708 & 3.542 & 82.635 & & & & & & \\
\hline 10 & 0.651 & 3.256 & 85.891 & & & & & & \\
\hline 11 & 0.525 & 2.626 & 88.517 & & & & & & \\
\hline 12 & 0.460 & 2.300 & 90.817 & & & & & & \\
\hline 13 & 0.366 & 1.832 & 92.649 & & & & & & \\
\hline 14 & 0.322 & 1.612 & 94.261 & & & & & & \\
\hline 15 & 0.301 & 1.505 & 95.766 & & & & & & \\
\hline 16 & 0.260 & 1.302 & 97.068 & & & & & & \\
\hline 17 & 0.215 & 1.075 & 98.143 & & & & & & \\
\hline 18 & 0.156 & 0.780 & 98.923 & & & & & & \\
\hline 19 & 0.124 & 0.619 & 99.542 & & & & & & \\
\hline 20 & 0.092 & 0.458 & 100.000 & & & & & & \\
\hline
\end{tabular}

Table 12: Component matrix.

\begin{tabular}{|c|c|c|c|c|}
\hline \multicolumn{5}{|c|}{ Component Matrix ${ }^{a}$} \\
\hline & \multicolumn{4}{|c|}{ Component } \\
\hline & 1 & 27 & 3 & 4 \\
\hline Q19 & 0.770 & 0.244 & & \\
\hline Q8 & 0.759 & -0.243 & & 0.292 \\
\hline Q12 & 0.724 & & 0.121 & -0.149 \\
\hline Q1 & 0.716 & -0.256 & 0.310 & -0.257 \\
\hline Q7 & 0.714 & -0.174 & -0.104 & 0.366 \\
\hline Q4 & 0.676 & -0.269 & 0.310 & \\
\hline Q3 & 0.664 & & 0.251 & -0.135 \\
\hline Q5 & 0.654 & 0.151 & -0.246 & -0.256 \\
\hline Q18 & 0.606 & & -0.546 & 0.186 \\
\hline Q16 & 0.534 & -0.132 & -0.313 & -0.463 \\
\hline Q6 & 0.508 & 0.201 & 0.330 & \\
\hline Q15 & 0.418 & -0.236 & -0.372 & 0.200 \\
\hline Q10 & & 0.773 & -0.218 & 0.183 \\
\hline Q14 & 0.293 & 0.692 & -0.266 & -0.183 \\
\hline Q20 & -0.239 & 0.676 & 0.293 & 0.329 \\
\hline Q13 & 0.309 & 0.583 & & -0.410 \\
\hline Q17 & 0.270 & 0.539 & -0.343 & 0.107 \\
\hline Q9 & 0.225 & & 0.646 & -0.134 \\
\hline Q11 & 0.278 & 0.296 & 0.532 & 0.443 \\
\hline Q2 & 0.423 & -0.112 & & 0.516 \\
\hline
\end{tabular}

Extraction Method: Principal Component Analysis.

a. 4 components extracted. 
Table 13: Group statistics of three components from factor analysis arranged by past teaching experience the VIP.

\begin{tabular}{|ll|c|c|c|c|}
\hline \multicolumn{5}{c}{ Group Statistics } \\
\hline Past & & N & Mean & $\begin{array}{c}\text { Std. } \\
\text { Deviation }\end{array}$ & $\begin{array}{c}\text { Std. Error } \\
\text { Mean }\end{array}$ \\
\hline T_Confidence & Yes & 21 & 4.2352 & 0.55052 & 0.12013 \\
& No & 42 & 3.6455 & 0.90261 & 0.13928 \\
\hline Lesson_Impact & Yes & 21 & 3.3971 & 0.54325 & 0.11855 \\
\hline \multirow{2}{*}{ Students_Contribution } & No & 42 & 3.1369 & 0.79106 & 0.12206 \\
& Yes & 21 & 3.6667 & 0.85635 & 0.18687 \\
\hline & No & 42 & 3.0833 & 0.98102 & 0.15137 \\
\hline
\end{tabular}

\section{Conclusion and Recommendations}

Despite the fact that this study has an exploratory character, results seem to indicate that faculty with experience teaching the visually impaired have a positive attitude towards teaching the visually impaired and most likely appreciate the presence of the visually impaired in the class. We suggest that at least in our institution where the survey was implemented that training and further faculty development be provided so we can better serve the visually impaired students. We also suggest that further research should be done in other institutions to evaluate faculty attitudes towards the visually impaired. Descriptive statistics as well as variability studies and Cronbach's Alpha were utilized to evaluate individual statements performance and internal consistency of the instrument developed. It seems that in general most teachers' scores indicate neutral to positive attitude towards teaching the visually impaired. Even though some biased responses may have been obtained and some refusal to respond some questions, we are confident, and training and faculty development may be crucial tool to help faculty manage an inclusive classroom where the visually impaired student may excel and contribute the class experience Table 14 .

Table 14: Independent sample t-test of components based on with and without past teaching experience.

\section{Independent Samples Test}

\begin{tabular}{|c|c|c|c|c|c|c|c|c|c|c|}
\hline & \multirow[b]{3}{*}{$\mathrm{F}$} & \multirow[b]{3}{*}{ Sig. } & \multicolumn{7}{|c|}{ t-test for Equality of Means } \\
\hline & & & & & & & Mean & Std. Error & Interva & of the \\
\hline & & & & $\mathrm{t}$ & df & Sig. (2-tailed) & Diffe rence & Diffe rence & Lower & Upper \\
\hline \multirow[t]{2}{*}{ T_Confidence } & $\begin{array}{l}\text { Equal variances } \\
\text { assum ed }\end{array}$ & 3.390 & 0.070 & 2.743 & 61 & 0.008 & 0.590 & 0.215 & 0.160 & 1.020 \\
\hline & $\begin{array}{l}\text { Equal variances not } \\
\text { assumed }\end{array}$ & & & 3.206 & 58.416 & 0.002 & 0.590 & 0.184 & 0.222 & 0.958 \\
\hline \multirow[t]{2}{*}{ Lesson_Impact } & $\begin{array}{l}\text { Equal variances } \\
\text { assumed }\end{array}$ & 1.445 & 0.234 & 1.354 & 61 & 0.181 & 0.260 & 0.192 & -0.124 & 0.645 \\
\hline & $\begin{array}{l}\text { Equal variances not } \\
\text { assumed }\end{array}$ & & & 1.529 & 54.827 & 0.132 & 0.260 & 0.170 & -0.081 & 0.601 \\
\hline \multirow[t]{2}{*}{ Students_Contribution } & $\begin{array}{l}\text { Equal variances } \\
\text { assumed }\end{array}$ & 0.028 & 0.867 & 2.317 & 61 & 0.024 & 0.583 & 0.252 & 0.080 & 1.087 \\
\hline & $\begin{array}{l}\text { Equal variances not } \\
\text { assumed }\end{array}$ & & & 2.426 & 45.336 & 0.019 & 0.583 & 0.240 & 0.099 & 1.068 \\
\hline
\end{tabular}

The Factor Analysis has identified 3 core factor that had a meaningful interpretation that may affect teachers' attitudes. They can be categorized as under 1- Teacher's confidence to teach the visually impaired, 2- Lesson impact due to the presence of the visually impaired in a regular classroom, and 3- the recognition of the visually impaired contribution to the enrichment of the classroom experience Table 15. These factors seem to indicate that experience with teaching the visually impaired enhance teacher's confidence to teach the visually impaired and recognition of the visually impaired contribution. The first factor, teacher's confidence, explains $28.7 \%$ of the variability on the performance of the open-ended question. It is necessary to have confidence in the ability to teach the visually impaired in order to faculty to feel comfortable teaching the visually impaired and training may be the option to build up confidence. The second factor the impact on the lesson plan, which was relatively neutral for both experienced and non-experienced faculty seems to be a factor that may improve with training and awareness of different tools and techniques that are available for the visually impaired and faculty to better communicate and enhance learning to incorporate in the lesson 
plan. This factor explains $13.5 \%$ of the variability of the performance of the open-ended questions and may be an area that should be focused to improve and emphasize during training and faculty development. The third factor, recognition of the visually impaired to the classroom is a consequence of experiencing the visually impaired student in the classroom. It may also be part of training as well as sharing experience of faculty that had taught the visually impaired in the past. This factor explains $10.1 \%$ of the variability on the performance of the open-ended questions. The findings of this study and the importance of training as a transformative tool to change teacher's' attitudes towards the visually impaired is in conformity with that of Korir, 2015 who have found that visually impaired student may excel far better than sighted students. Korir also admits that most teachers do not have the skills to handle the visually impaired in the classroom as the source of negative attitude towards the visually impaired student.

Table 15: Correlation between the three components.

\begin{tabular}{|c|c|c|c|c|}
\hline \multicolumn{5}{|c|}{ Correlations } \\
\hline & & T_Confidence & Lesson_Impact & Students_Contribution \\
\hline \multirow[t]{3}{*}{ T_Confidence } & $\begin{array}{l}\text { Pearson } \\
\text { Correlation }\end{array}$ & 1 & 0.226 & $.289^{*}$ \\
\hline & Sig. (2-tailed) & & 0.073 & 0.020 \\
\hline & $\mathrm{N}$ & 64 & 64 & 64 \\
\hline \multirow[t]{3}{*}{ Lesson_Impact } & $\begin{array}{l}\text { Pearson } \\
\text { Correlation }\end{array}$ & 0.226 & 1 & $.261^{*}$ \\
\hline & Sig. (2-tailed) & 0.073 & & 0.038 \\
\hline & $\mathrm{N}$ & 64 & 64 & 64 \\
\hline \multirow[t]{3}{*}{ Students_Contribution } & $\begin{array}{l}\text { Pearson } \\
\text { Correlation }\end{array}$ & $.289^{*}$ & $.261^{*}$ & 1 \\
\hline & Sig. (2-tailed) & 0.020 & 0.038 & \\
\hline & $\mathrm{N}$ & 64 & 64 & 64 \\
\hline
\end{tabular}

\section{References}

1. Beal C R, Shaw E (2008) Working memory and math problem solving by blind middle and high school students: implications for universal access. Paper presented at the 19th International Conference of the Society for Information Technology and Teacher Education.

2. Lamichhane K (2017) Teaching students with visual impairments in an inclusive educational setting: a case from Nepal. International Journal of Inclusive Education 21(1).

3. Hull J (2002) Rehabilitation of visually impaired learners. University Press, New York, USA.

4. Hehir, Thomas, (2016) A Summary of the Evidence on Inclusive Education.

5. Waldron N, Cole C (2000) The Indiana Inclusion Study Year 1 Final Report.

6. Rooks-Ellis D L (2014) Inquiry-Based Education for Students with Visual Impairment.

7. Mergendoller J R, Maxwell N L, Bellisimo Y (2006) The effectiveness of problem-based instruction: A Comparative Study of instructional methods and student characteristics.

8. Oluremi F D (2015) Attitude of Teachers to Students with Special Needs in Mainstreamed Public Secondary Schools in Southwestern Nigeria: The Need for a Change. European Scientific Journal 11(10): 194-209.
9. Argyris C (2007) The Conflict between system and the individual. Personality and Organization.

10. George D, Mallery P (2003) SPSS for Windows step by step: A simple guide and reference. 11.0 update $\left(4^{\text {th }}\right.$ edn) Boston: Allyn \& Bacon.

11. Dancey C, Reidy J (2004) Statistics Without Maths for Psychology: Using SPSS for Windows. London: Prentice Hall.

12. Baraga C (2006) Visual handicaps and learning. A developmental approach.

13. Besson, Nalida E L (2002) Attitudes and Policies on Blindness/Visual Impairment and Braille Literacy.

14. Jones T (2011) An empirical study of children's use of computer pointing devices. Journal of Educational Computing Research 7(1): 61-76.

15. Korir B C (2015) The Perception of Students and Teachers on the Intergration Program of Students with Visually Impairment in Secondary Schools: A Case of Ainamoi Sub Country, Kericho Country, Kenya, Journal of Education and Practice 6(12).

16. (1999) National Federation of the Blind, homepage.

17. (2017) National Federation of the Blind, homepage.

18. Orodho J A (2004) Techniques of Writing Research Proposal and Reports in Education and Social Sciences. Masola Publishers, Nairobi, Kenya.

19. Patton (2010) Qualitative Evaluation and Research. ( $2^{\text {nd }}$ edn.) CA Sage Publication, USA. 


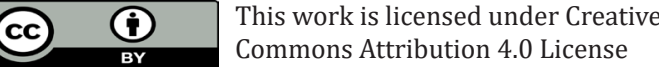

To Submit Your Article Click Here: Submit Article

DOI: $10.32474 /$ SJPBS.2019.02.000137

\begin{tabular}{|l|l|}
\hline SJPBS & $\begin{array}{c}\text { Scholarly Journal of Psychology } \\
\text { and Behavioral Sciences }\end{array}$ \\
Assets of Publishing with us
\end{tabular}

